\title{
Analysis of Compensation System Based on Job Value of Indonesian Cooks in Kuala Lumpur
}

\author{
Afrisca Azumanul Hakim ${ }^{1 *}$, Lindawati Kartika ${ }^{2}$, and Zuraina Dato' \\ Mansor $^{3}$ \\ ${ }^{1,2}$ Bogor Agricultural University, Bogor, Indonesia \\ ${ }^{3}$ University of Putra Malaysia, Serdang, Malaysia
}

\begin{abstract}
Indonesian cooks is a kind of job that has a great potential to be developed, considering the high enthusiasm for Indonesian dishes in Malaysia and the popularity of Indonesian food in the world. This research aims to analyze the condition of compensation system currently applied to Indonesian Migrant Workers at cooks job cluster in Kuala Lumpur, as well as to identify the compensable factors, and to analyze the ideal compensation system. Data used in this research are primary data (questionnaire) and secondary data (literature study). This research used descriptive analysis, salary mapping analysis, point system method, and linear regression test in order to process the data. Result of the research shows (1) The evaluation result of Indonesian Migrant Cooks' salary distribution has not been ideal entirely; (2) Compensable factors that used are knowledge and skill, organizational capabilities, self reliance, self presentation, responsibility of supervising, responses to critics, and the influence of work result; (3) The ideal compensation system for Indonesian Migrant Cooks in KL is non classification system based on Hay Plan Method, which the required funding is more efficient with amount RM 4,036.99 or about Rp.12,918,368.00.
\end{abstract}

Keywords: Compensation System, Indonesian migrant workers

\section{INTRODUCTION}

ASEAN Economic Community (AEC) is an economic integration agenda from ASEAN member states that aims to reduce economic barriers among Southeast Asian states. Began in early 2016, AEC ensures the free flow of investment, capital, skill workers, goods and services in 10 ASEAN member states. According to a research by International Labor Organization (ILO) in 2015, AEC will increase the demand of professional workers as much as $41 \%$ or approximately 38 million workers, the demand of middle level workers $24 \%$ or 14 million workers, and for low level workers, $24 \%$ or 12 million workers. The increased demand for workers is an opportunity for ASEAN member states to solve the domestic unemployment problem in some states.

Accounted as the world's fourth largest population, Indonesia is also accounted as one of the world's largest exporter of labours amongst the ASEAN members. According to Act No.39 year 2004, Indonesian migrant worker is every Indonesian citizen who are eligible to work abroad under the status of employment

\footnotetext{
* Corresponding author. Email address: afrisca.azhak@gmail.com
} 
for a certain period of time with a wage. Indonesian migrant workers are often referred as foreign exchange heroes since their remittances from working abroad, is second in line after the income from oil and gas sector for contributing about $10 \%$ of the value of the Indonesia's state budget (Bank of Indonesia, 2013).

However, the high remittances of these migrants cannot be compared to the situation and conditions that they have to undergo, such as assault, unpaid wages, and so on (BNP2TKI, 2015). In responding to this, the government of Indonesia has attempted to improve the protection of Indonesian migrant workers by reducing the number of informal migrant workers annually. It is supported by moratorium regulations, which functions to temporarily reduce the influx of workers abroad as well as to reduce the number of Indonesian workers in informal sectors in several countries. According to BNP2TKI (The National Institution of Indonesian Migrant Placement and Protection) Indonesian informal migrant workers refer to those who are working abroad for individual employer with the absence of a binding law that leads to a subjective working relations and vulnerability towards complication. A large number of Indonesian informal workers caused by the low level of education in Indonesia. This is shown in Figure 1.
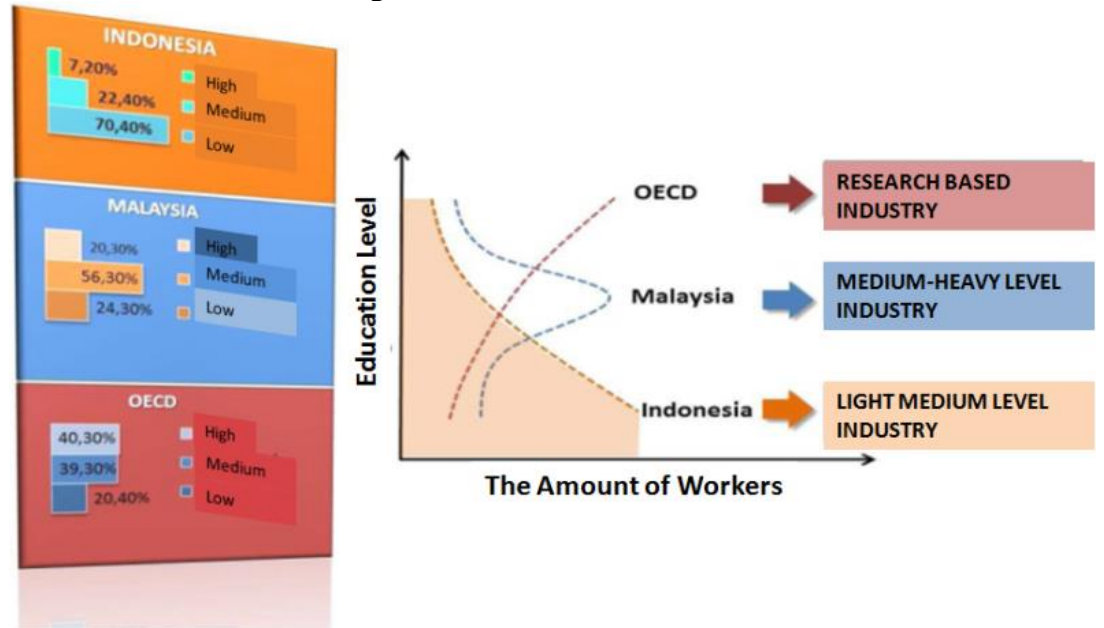

Figure 1 Human Resources Quality in Indonesia and Other Countries (Source: Ministry of Trade of the Republic of Indonesia, 2016)

Based on Figure 1, human resources in Indonesia are still dominated by education at a base level of $70.40 \%$. Comparing to other Southeast Asia countries such as Malaysia, Indonesia is still slightly behind from dominating the growing industries, and still developing on the light medium level industry.

Indonesia and Malaysia are two member states of ASEAN with common roots, history, and geographical proximity. In terms of Indonesian migrant workers, Malaysia serves as one of their primary destination from 2011 to 2015. This is shown in Figure 2. 


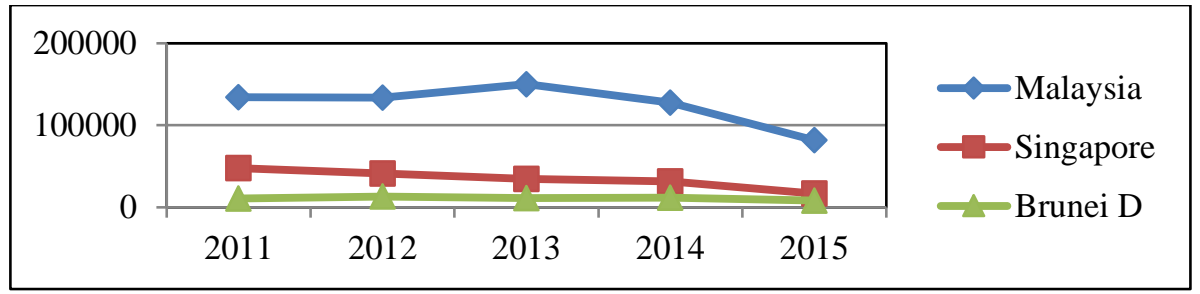

Figure 2 Placement of Indonesian Workers in Foreign Countries in 2011-2015

(Source: BNP2TKI, 2015)

Among the other destination countries both in Southeast Asia and in the world, Malaysia is occupying the first position as a destination country with the largest number of migrant workers. In 2008, Malaysia was also the main destination for migrant workers in Southeast Asia (Kaur, 2008). The ease of getting a job, higher salary, various work opportunities, and geographical proximity attract many Indonesian workers both in formal or informal sector to seek an opportunity in Malaysia. It supported by the study of Mansor (2014) who discovered that employee willingness to accept international assignment can be affected by their assumptions about cultural similarity between their home country and the host country. Kaur (2008) found that the reason of Indonesian workers migrating to Malaysia is because of the similar language, culture, and religion. Martin (2003) also revealed the factors which encourage people to migrate are the economic and non economic reasons both in terms of the attractiveness of labor demand, labor supply encouragement, and information transformation network. As previously mentioned, sending Indonesian workers to work abroad have indeed contributed to the state's budget, but not only that, they also reduce the number of unemployment, increase foreign exchange, as well as the development of rural areas of their origin (Republika.co.id, 2015 and Tribunnews.com, 2013). However sending workers abroad also inflicted a lot of problems such as assault, sexual harassment and even murder as they are often despised due to their job as domestic workers (voaindonesia.com, 2015). In Malaysia, Indonesian migrant workers are mostly working on the 3D sector known as dirty, dangerous and difficult such as construction, plantation and restaurant services sector, as most Malaysians detest to work in this 3D sector (BBC.com, 2016).

In 2015, Ministry of Manpower of the Republic of Indonesia issued a regulation (Ministry of Manpower's Regulation No.1 /2015) regarding the change of the classification of 7 informal working fields to formal work for migrant workers, one of them is as a cook.

Indonesian cook is one of the jobs with highest development potential. This is supported by the popularity of Indonesian culinary that offers combination of peculiar spices and taste. Some Indonesian dishes have been praised as the most delicious food in the world, such as Rendang and NasiGoreng (fried rice) that placed first and second as the world's most delicious food according to World's 50 Best Food in 2011. Satay, another Indonesian original dish, also successfully placed in the 14th position of world's best food according to CNN in 2011. World's enthusiasm for Indonesian food is very significant, including in Kuala Lumpur. In this recent times, Ayam Penyet, a dish originating from Java, has greatly been demanded. Ayam Penyet dishes even have become a franchise business with many 
different brands such as Ayam Penyet AP which has 26 outlet branches in Malaysia and Ayam Penyet Ria which has 9 outlet branches in Malaysia, and many more Ayam Penyet brands in Malaysia (antaranews.com, 2011 and finance.detik.com, 2014). This indicates that Indonesian cook is a potential job to be developed in Malaysia especially in Kuala Lumpur.

\section{LITERATURE STUDY}

Human resource is the most valuable asset which has the greatest potential in determining the performance and achievement of an organization. Some studies related to the analysis of the compensation system are done considering the importance of compensation for human resources in companies and in order to achieve success in a company itself. At the previous research, Hatman (20016) found that the compensation system in CV. Indopress Cemerlang still needs improvement. $50 \%$ levels of the job are not in ideal condition. Compensable factors in CV. Indopress Cemerlang are experience, responsibility to supervise, consequences of errors, problem solving, working condition and level of independence.

Another research which conducted by Yusliana (2012) also found that there were 16 indicators which used to determine the amount of incentives for education personnel who are civil servants in the Bogor Agricultural University. Assessment of work quality has the greatest weight than other indicators. In 2013, Safdar also found that the compensable factors which used at the Job Evaluation for Humanitarian Actors in Health Sector of Pakistan were experience, education, working zones, and job status. The proposed salary of Doctors in various specialization was varying from minimum to maximum salary. Data at Safdar's research had poor coordination with scoring system. Staff with highest score was having least salary and those having least score were receiving maximum salary. Safdar's research also suggests a new salary structure.

Based on some previous studies, such the studies which had been carried out by Hatman, Yusliana, Safdar, it is obtained that the compensation system in several companies is not yet ideal. It implies that the internal equity has not been reached on some of those conditions. The previous studies also found the factors which underlying the nominal payroll in specific type of job that had been studied. Based on previous researches by Hatman, Yusliana, Safdar, and Sun, and the presence of Ministry of Manpower's regulation No.1/2015 which stated that cooks is one of the jobs which will be enhanced from informal to the formal sector or later Indonesian cooks will work with employers who incorporated in legal entities, author is interested to do a research regarding compensation system analysis based on job value of Indonesian migrant for cooks job cluster in Kuala Lumpur, Malaysia. This study focuses on the assessment system of compensation received by TKI cook at home industry level who work in Kuala Lumpur, Malaysia.

\section{RESEARCH METHODOLOGY}

\section{Sampling Method}

Sampling method in this research is non probability sampling with purposive sampling techniques and convenience sampling. The sample numbers in this study were 14 experts, and 30 samples of Indonesian cooks. The sample used 
as resource persons in this study include: (1) one representative from Expert Assessor of Indonesian Chef Association; (2) one representative from Owner of the Restaurant in Indonesia (3) one Human Resources Management Expert (The Expert Lecturer of Human Resource Management, University of Indonesia); (4) 11 shop owners that employ Indonesian cooks of home industry level in Kuala Lumpur, Malaysia; (5) 30 Indonesian Migrant Workers who works as cooks in home industry level, Kuala Lumpur, Malaysia.

Statistical Descriptive Analysis

According Sugiono (2010) descriptive statistics are statistics which used to analyze data by describing the data that has been collected without intention to create a generally applicable conclusion.

Salary Mapping Analysis

Salary mapping analysis is used to determine the percentage of the range spread and mid to mid in every level of existing positions. The good conditions of salary structure is the condition where the presentation of mid to mid is smaller than the percentage of range spread in a position level.

Point System Method

Through the point method, appraisers allocate the numeric values towards the job specific factors, and the numbers of these values provide a quantitative assessment of the relative job value (Mondy 2008). Point system method steps that were taken this study include:

1. Choose the Work Group

2. Identify the Compensable Factors

3. Determine the Level and Define Every Compensation Factors

4. Determine the Weight of Factors

Weighting techniques used in this study is the Eckenrode weighting method.

5. Determine the Factor Point Value

6. Validate the Point System

7. Calculate the Job Point of Workers

8. Determine the Price of Works

9. Calculate the Pay Ranges

10. Calculate the Pay Grades

11. Adjustments

Points system will indicate the actual salary conditions:

a. Under paid, indicating that actual salaries are lower than the bottom margin salary

b. In paid, indicating that actual salaries are in the right position, which is located between the bottom and the upper margin salary

c. Over paid, indicating that actual salaries are higher than the upper margin salary

12. Ideal Compensation System Making

At the under paid a salary, actual salaries should be increased to the bottom margin salary. In paid salary does not need to be changed or adjusted because it is in the right conditions. The over paid salary could not be changed, because every salary could not be downgraded.

\section{Collect Data}

The research was conducted in Kuala Lumpur, Malaysia in January 2016 April 2016. Data used in this research were primary and secondary data. The questionnaire in this study is divided into two types. The first type of questionnaire 
was aimed to determine the rating of compensable factors, this was distributed to the experts. The second type of questionnaire was distributed to Indonesian workers on cooks job cluster at home industry level in Kuala Lumpur in order to know the aspects of workers' compensation received. In this research, secondary data are taken from Ministry of Labor of the Republic of Indonesia and the BNP2TKI, the Indonesian Embassy in Malaysia, books, internet, theses and the relevant journals.

\section{RESULTS}

The main object of this research is the Indonesian migrant workers who work as a cook at home industry level or equivalent with SMEs or shops in Kuala Lumpur, Malaysia. The Indonesian Cooks who become samples in this research work for the shops at Chow Kit, Kampung Baru and Kampung Bandan area of Kuala Lumpur, Malaysia.

The Compensation System Condition of Indonesian Migrant Workers at Cooks Job Cluster in Home Industry Level, Kuala Lumpur

According to survey which conducted by researcher, Indonesian cooks in $\mathrm{KL}$ at home industry level have an average basic salary of RM 1,642. Overall, the Indonesian cooks receive a fixed allowance for meal, and holiday allowance, but not all Indonesian migrant workers who work as cook receive bonus, as it is dependent on the policy of shop owner. This could be seen in Table 1.

Table 1 The Condition of Compensation Component which Received by Indonesian Cooks at Home Industry Level in Kuala Lumpur 2016

\begin{tabular}{|c|c|c|c|c|c|c|c|c|c|c|c|c|}
\hline \multirow[b]{3}{*}{ Position } & \multirow[b]{3}{*}{$\begin{array}{c}\text { Total } \\
\text { Person }\end{array}$} & \multicolumn{2}{|c|}{ Basic Salary } & \multicolumn{2}{|c|}{$\begin{array}{l}\text { The Average of } \\
\text { Basic Salary }\end{array}$} & \multicolumn{7}{|c|}{$\%$ of Total Receiver (Person) } \\
\hline & & \multirow[b]{2}{*}{$\mathbf{R M}$} & \multirow[b]{2}{*}{$\mathbf{R p}$} & \multirow[b]{2}{*}{$\mathbf{R M}$} & \multirow[b]{2}{*}{$\mathbf{R p}$} & \multicolumn{4}{|c|}{$\begin{array}{c}\text { Direct Financial } \\
\text { Compensation }\end{array}$} & \multicolumn{3}{|c|}{$\begin{array}{c}\text { Indirect Financial } \\
\text { Compensation }\end{array}$} \\
\hline & & & & & & 莺 & $\sum^{\infty}$ & 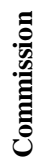 & $\stackrel{\mathscr{Z}}{\Xi}$ & $\sum^{\bar{g}}$ & 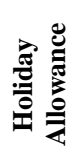 & 롶 \\
\hline Cooks & 21 & $\begin{array}{c}1,200 \\
- \\
3,000\end{array}$ & $\begin{array}{c}3,840,000.00 \\
- \\
9,600,000.00\end{array}$ & 1,731 & $5,539,000.00$ & 100 & 38.1 & 0 & 38.1 & 100 & 100 & 57.1 \\
\hline $\begin{array}{l}\text { Senior } \\
\text { Cooks } \\
\text { Assistant }\end{array}$ & 7 & $\begin{array}{c}1,100 \\
- \\
2,100\end{array}$ & $\begin{array}{c}3,520,000,00 \\
- \\
6,720,000.00\end{array}$ & 1,414 & $4,524,800.00$ & 100 & 14.29 & 0 & 14.2 & 100 & 100 & 71.4 \\
\hline $\begin{array}{l}\text { Junior } \\
\text { Cooks } \\
\text { Assistant }\end{array}$ & 2 & 1,500 & $4,800,000.00$ & 1,500 & $4,800,000.00$ & 100 & 0 & 0 & 50 & 100 & 100 & 100 \\
\hline TOTAL & & & & & & & & & & & & \\
\hline
\end{tabular}

Source: Data processed (2016)

Table 1 explains that Indonesian cooks at home industry level in KL have a basic salary that is already above the workers minimum wage in Malaysia which is RM 900 based on the agreement between the government of Malaysia and Indonesia (finance.detik.com, 2015), but not all of Indonesian cooks receive the complete remuneration package. From 21 positions of Cooks Position and seven Senior Cooks Assistant, there are eight cooks and one Senior Cooks Assistant 
where their workplace applies wage system through the implementation of overtime and bonuses when the shop get many visitors. From the total sample of Indonesian Cooks, there are 19 Cooks who received health reimbursements from the shop owner when they get ill.

The Salary Mapping of Indonesian Cooks in Kuala Lumpur, 2016

The condition of compensation system which currently implemented on Indonesian migrant workers at cooks job cluster for home industry level in Kuala Lumpur is able to be observed from the salary mapping based on job position.

Table 2 Salary Mapping Result

\begin{tabular}{|c|c|c|c|c|c|c|c|c|}
\hline \multirow[b]{2}{*}{$\begin{array}{c}\text { Job } \\
\text { Position }\end{array}$} & \multirow[b]{2}{*}{$\begin{array}{c}\text { Total } \\
\text { Person }\end{array}$} & \multirow[b]{2}{*}{$\begin{array}{l}\text { Total } \\
\text { Salary } \\
(\mathbf{R M})\end{array}$} & \multicolumn{3}{|c|}{ Actual (RM) } & \multicolumn{2}{|c|}{ Actual } & \multirow[b]{2}{*}{ Explanation } \\
\hline & & & Min & Average & Max & $\begin{array}{l}\text { Mid } \\
\text { to } \\
\text { Mid }\end{array}$ & Spread & \\
\hline Cooks & 21 & 44,003 & $\begin{array}{l}1,35 \\
8\end{array}$ & $2,095.38$ & 3,375 & $\begin{array}{l}21.36 \\
\%\end{array}$ & $\begin{array}{l}148.53 \\
\%\end{array}$ & $\begin{array}{l}\text { Ideal, but the } \\
\text { Range Spread } \\
\text { is very large }\end{array}$ \\
\hline $\begin{array}{l}\text { Senior } \\
\text { Cooks } \\
\text { Assistant }\end{array}$ & 7 & 12,086 & $\begin{array}{l}1,40 \\
8\end{array}$ & $1,726.57$ & 2,408 & $\begin{array}{l}- \\
6.57 \\
\%\end{array}$ & $\begin{array}{l}71.02 \\
\%\end{array}$ & $\begin{array}{l}\text { Ideal, but the } \\
\text { mid to mid } \\
\text { percentage is } \\
\text { less } \\
\text { appropriate } \\
\text { because it is } \\
\text { negative }\end{array}$ \\
\hline $\begin{array}{l}\text { Junior } \\
\text { Cooks } \\
\text { Assistant }\end{array}$ & 2 & 3,696 & $\begin{array}{l}1,80 \\
8\end{array}$ & $1,848.00$ & 1,888 & - & $4.42 \%$ & Ideal \\
\hline
\end{tabular}

Source: Data processed (2016)

Table 2 explains that the spread value on the actual compensation condition for Cooks position is ideal, for it is greater than mid to mid value (148.53\% > $21.36 \%$ ). Mid to mid which is smaller than the spread indicates that the salary increase that occurred on the job level is not too extreme. But the spread value that still less suitable due to the spread value in these conditions is very large which is more than $100 \%$ and dispersed at every position level, where the spread value at Cooks position is more than $100 \%$. It describes the respondents' salary distribution are considerable enough for every job level in cooks job cluster, therefore it is less than ideal and should be fixed. Moreover, the mid to mid value for Senior Cooks Assistant is also less suitable as its value is negative, where mid to mid value should be positive. The negative value is caused due to the average salary value of the lower positions is greater than the average salary value of the Senior Cooks Assistant $(1,848.00>1,726.57)$, and it should be revised. 


\section{DISCUSSION}

\section{Job Value Calculation of Indonesian Cooks in Kuala Lumpur 2016}

In this study, compensable factors are formulated based on the Hay Plan Method, cooks' appraisal on form Chef Resources official website www.chefsresources.com, and Indonesian Government Regulation on KEP.217/MEN/VII/2009 on SKKNI Social Services Sector and Individual Services Sector Enterprises Food. Compensable factors are sorted from the most important to least important factor by experts through questionnaires. The results of compensable factors rating is then used to calculate the weight of job value using Eckenrode methods.

Table 3 The Result of Point System

\begin{tabular}{lcccccc}
\hline \multirow{2}{*}{ Factor } & Weight & \multicolumn{6}{c}{ Level } \\
\cline { 3 - 7 } & & $\mathbf{1}$ & $\mathbf{2}$ & $\mathbf{3}$ & $\mathbf{4}$ & $\mathbf{5}$ \\
\hline Knowledge and Skill & 27.78 & 27.78 & 90.29 & 152.79 & 215.30 & 277.80 \\
Self Presentation & 14.24 & 14.24 & 56.96 & 99.68 & 142.40 & \\
Organizational Capabilities & 16.32 & 16.32 & 53.04 & 89.76 & 126.48 & 163.20 \\
Responses to Critics & 9.72 & 9.72 & 38.88 & 68.04 & 97.20 & \\
Self Reliance & 15.28 & 15.28 & 61.12 & 106.96 & 152.80 & \\
Responsibility of Supervising & 13.89 & 13.89 & 55.56 & 97.23 & 138.90 & \\
The Influence of Work Result & 2.78 & 2.78 & 15.29 & 27.80 & & \\
\hline
\end{tabular}

Source: Data processed (2016)

Table 3 shows that knowledge and skills factor is a main aspect which is used in hiring Indonesian cooks. Furthermore, the weight of each level at every compensable factor was used to analyze the job value of every Indonesian cooks that will be examined by processing the questionnaire results.

\section{Points System for Job Position on Indonesian Cooks in Kuala Lumpur 2016}

To determine the value of the job point on every worker who works as cooks at each position, the researcher analyze the job value of every aspect through questionnaires that has been given to Indonesian cooks. Job value aspects are analyzed and rated in accordance with the result of the points system at every level of compensable factors which is obtained in the preceding stage. 
Table 4 Job Point of Indonesian Cooks at home industry level in Kuala Lumpur 2016

\begin{tabular}{clllllllll}
\hline No & Name & $\begin{array}{c}\text { Location } \\
\text { of Work }\end{array}$ & Position & $\begin{array}{c}\text { Job } \\
\text { Point }\end{array}$ & No & Name & $\begin{array}{c}\text { Location } \\
\text { of Work }\end{array}$ & Position & $\begin{array}{c}\text { Job } \\
\text { Point }\end{array}$ \\
\hline 1 & R1 & KB1 & C & 792.26 & 16 & R7 & CK2 & C & 433.64 \\
2 & R2 & KB1 & C & 792.26 & 17 & R26 & CK1 & C & 371.14 \\
3 & R17 & CK4 & C & 772.48 & 18 & R27 & KB4 & C & 371.14 \\
4 & R16 & CK4 & C & 670.37 & 19 & R24 & KB3 & C & 337.79 \\
5 & R3 & KB2 & C & 649.54 & 20 & R12 & CK3 & C & 337.79 \\
6 & R9 & KB4 & C & 603.7 & 21 & R11 & CK3 & C & 308.63 \\
7 & R4 & KB3 & C & 587.03 & 22 & R23 & KB2 & SCA & 430.51 \\
8 & R5 & CK1 & C & 582.86 & 23 & R14 & KB5 & SCA & 387.79 \\
9 & R19 & CK4 & C & 563.08 & 24 & R15 & KB5 & SCA & 384.67 \\
10 & R18 & CK4 & C & 562.03 & 25 & R13 & CK3 & SCA & 341.95 \\
11 & R6 & CK2 & C & 548.24 & 26 & R28 & KB6 & SCA & 306.29 \\
12 & R8 & KB4 & C & 541.19 & 27 & R25 & KB3 & SCA & 299.23 \\
13 & R21 & CK4 & C & 510.98 & 28 & R22 & KB1 & SCA & 279.44 \\
14 & R10 & KBd1 & C & 489.62 & 29 & R30 & KBd1 & JCA & 230.21 \\
15 & R20 & CK4 & C & 448.48 & 30 & R29 & CK1 & JCA & 224.21 \\
\hline
\end{tabular}

Notes. $\mathrm{R}=$ Respondent; $\mathrm{KB}=$ Kampung Baru; $\mathrm{CK}=$ Chow Kit; $\mathrm{KBd}=$ Kampung Bandan; $\mathrm{C}=$ Cooks; $\mathrm{SCA}=$ Senior Cooks Assistant; JCA= Junior Cooks Assistant

Source: Data processed (2016)

Table 4 shows that the Cooks has the highest value of job point. This is due to the skills, abilities, and high capacity of cooks that also possess a significant value to the results of the job point analysis of the Cooks. Table 6 also depicted that the position of Junior Cooks Assistant has the lowest value the job point. It is due to the skills, abilities, and capacity which are low in this position create the value of the job point analysis of JCA position become low.

The Job Value Effect toward Actual Salaries of Indonesian Cooks in Kuala Lumpur 2016 through the Regression Analysis

After obtaining the job point value of every cooks worker, the next step is finding the linear equations by using the job point as the variable $\mathrm{x}$ and actual salaries (all-in) as the variable y. 
Table 5 Regression Analysis between Job Point and Actual Salaries

\begin{tabular}{|c|c|c|c|c|c|c|}
\hline \multicolumn{7}{|c|}{ Coefficients $^{a}$} \\
\hline & \multirow[b]{2}{*}{ Model } & \multicolumn{2}{|c|}{$\begin{array}{c}\text { Unstandardized } \\
\text { Coefficients }\end{array}$} & \multirow{2}{*}{$\begin{array}{c}\begin{array}{c}\text { Standardized } \\
\text { Coefficients }\end{array} \\
\text { Beta }\end{array}$} & \multirow[t]{2}{*}{$\mathbf{t}$} & \multirow[t]{2}{*}{ Sig. } \\
\hline & & B & Std. Error & & & \\
\hline \multirow[t]{2}{*}{1} & (Constant) & 1108.368 & 226.921 & & 4.884 & .000 \\
\hline & job point & 1.874 & .455 & .614 & 4.116 & .000 \\
\hline
\end{tabular}

Source: Data processed (2016)

Table 5 shows that the regression equation to see the effect of job value on actual salaries of Indonesian Cooks is $\mathrm{y}=1108.368+1.874059 x$. This equation shows that if the job point of Indonesian Cooks increase for 1(one) unit, the actual salaries will rise to RM 1.874059. The regression $y=1108.368+1.874059 x$ shows that the actual salaries which is showed as y variable is depends on job point as the $\mathrm{x}$ variable. If the job point is lower, the actual salaries will show the lower value too. If the job point has an increasing value, the actual salary should be rise up. Then, the regression equation is used to calculate a midpoint salary of each position to determine the value of the bottom margin and the upper margin salary of each position.

\section{Non Classification of Compensation System}

Midpoint salary in this study was obtained by the formula $y=1108.368+$ $1.874059 x$. Pay ranges of Indonesian cooks is $3 \%$ which derived from the average of salary increase received by workers. Interval bottom margin of salary and the upper margin salary of Indonesian cooks is $6 \%$, where the bottom margin of salary is $97 \%$ of the midpoint salary, and the upper margin salary is $103 \%$ of the midpoint salary. To this extend, the salary received by Indonesian cooks can be categorised into three condition; in paid or appropriate, over paid and under paid. The detail results of Indonesian Cooks compensation condition by non classification calculation could be seen Table 6 .

Table 6 Analysis of Non Classification Salary Structure

\begin{tabular}{|c|c|c|c|c|}
\hline Position & $\begin{array}{c}\text { Total } \\
\text { Person } \\
\end{array}$ & UP & IP & $\mathbf{O P}$ \\
\hline Cooks & 21 & 10 & 3 & 8 \\
\hline Senior Cooks Assistant & 7 & 5 & 0 & 2 \\
\hline Junior Cooks Assistant & 2 & 0 & 0 & 2 \\
\hline Total & 30 & 15 & 3 & 12 \\
\hline
\end{tabular}

Source: Data processed (2016)

The under paid salary should be pulled up into the bottom margin salaries as it is the minimum salary that must be paid aligned with the job value of Indonesian cooks. On the other hand, the over paid salary shall remain as it is 
essentially the employee's salary and cannot be downgraded, but it could be resolved by extending the work of the migrant workers in order to balance out the over paid salary. In the previous research, Pandey (2012) found that people and their motivation is dependent upon how well they are being paid. Trevor (2006) also found that pay dispersion had stronger negative effects on satisfaction and commitment for those who had lower salaries. Therefore the adjustment salary which calculated based on job evaluation was needed to enhance the external and internal consistency.

Adjustment of ideal salary is conducted in order to diminish the imbalance of salaries ranging from the bottom margin of salary and the upper margin of salary or in paid. Adjustments are made to raise the upper margin of salary range by $41 \%$ that is obtained by multiplying midpoint salary by $144 \%$. Under the non classification system of compensation, the total actual salaries that are issued monthly for Indonesian cooks amounte to RM 59.785 for the total of 11 shops which employ Indonesian cooks (the total of 30 Indonesian Cooks). Through the ideal compensation for non classification system, total salaries which necessary to be issued in a month amounted to RM 63,821.99 for the total of 11 shops for also the total of 30 Indonesian cooks which are being the sample respondent in this research, where the number of difference between the ideal salary and the current salary which not appropriate is amounted to RM 4,036.99 for seven shops that employ Indonesian Cooks which the salary is identified in under paid condition.

\section{The Classification of Compensation System}

In providing a comprehensive research, the compensation system is also calculated with the classification system to compare the results between the non classification and classification calculations in order to show the most efficient alternative in solving the loopholes of the existing compensation system. Pay ranges used in Figure 7 is $6 \%$, where the bottom margin of salary is $97 \%$ of the midpoint salary, and the upper margin of salary is $103 \%$ of the midpoint salary. It is obtained from the average increase salary for Indonesian cooks, that is $3 \%$. The result of the classification of compensation system is shown in Table 7.

Table 7 The Result of Classification Compensation System

\begin{tabular}{lllll}
\hline \multicolumn{1}{c}{ Group } & Total & UP & IP & OP \\
\hline III & 6 & 4 & 0 & 2 \\
II & 11 & 4 & 5 & 2 \\
I & 13 & 4 & 0 & 9 \\
\hline Total & 30 & 12 & 5 & 13 \\
\hline Notes. UP=Under Paid; IP=In Paid; OP=Over Paid \\
\hline
\end{tabular}

Source: Data processed (2016)

Table 7 expalins there are 12 Indonesian cooks whose salary are in under paid condition, 5 Indonesian cooks that are in paid condition, and 13 Indonesian cooks with the overpaid conditions of actual salary. This step is followed by salary adjustment of Indonesian cooks which indicated in under paid condition. Adjustments are made by tugging the under paid salaries to be in paid into the 
bottom margin salaries and raise the upper margin of salary for $47 \%$. Upper margin of salary is $150 \%$ of the midpoint salary.

After being adjusted, all salaries are in the condition of in paid or appropriate in the range between the bottom margin of salary and the upper margin of salary. Total salary issued on the actual conditions in which many Indonesian cooks salaries are in unsuitable conditions is amounted to RM 59.785 for the total of 11 shops which employ Indonesian cooks. In order to achieve the ideal system of classification, the total compensation that needs to be issued must amount to RM $64,733.07$ monthly per the total of 11 shops that employ 30 Indonesian cooks. The gap between ideal salary and the current salary is inappropriate as it amounts only RM 4,948.07 for eight shops that employ Indonesian cooks in which the salary have been indicated in the under paid condition.

\section{CONCLUSION}

\section{Managerial Implications}

Based on the analysis of this study, Indonesian Cooks' salary are already above the minimum salary policy of Indonesian workers in Malaysia, but have not reached the average salary standard based on the salary survey that was conducted with a calculation of the compensation system on the existing of Indonesian Cooks in KL. Indonesian Cooks salaries which are on under paid condition should be increased, therefore the job value will appropriate through the salary amount and achieve the equity. The difference details of actual salary received by Indonesian cooks, the ideal of non classification salary, and the ideal of classification salary could be seen in Table 8 .

Table 8 The Difference of Actual Salary Received by Indonesian Cooks In 2016, Ideal Salary Based on Non Classification System and the Ideal Salary Based on Classification System

\begin{tabular}{|c|c|c|c|}
\hline & $\begin{array}{c}\text { Actual Salary } \\
\text { Amounts of } \\
\text { Indonesian Cooks } \\
\text { in February,2016 } \\
\text { (RM) }\end{array}$ & $\begin{array}{c}\text { The Ideal } \\
\text { Salary } \\
\text { through Non } \\
\text { Classification } \\
\text { System } \\
\text { (RM) } \\
\end{array}$ & $\begin{array}{c}\text { The Ideal Salary } \\
\text { through } \\
\text { Classification } \\
\text { System }(\mathrm{RM})\end{array}$ \\
\hline Total Salary & 59,785 & $63,821.99$ & $64,733.07$ \\
\hline Difference in price & & $* 4,036.99$ & $4,948.07$ \\
\hline
\end{tabular}

\section{Source: Data processed (2016)}

The difference of the actual salary received by Indonesian cooks in February 2016 with the the ideal salary through non classification system has the lowest gap when its being compared through the gap of the ideal salary of classifications which amounts to RM 4,036.99 or about Rp.12,918,368.00. It concludes that the more efficient ideal compensation system to be applied in revamping of the existing compensation system for Indonesian cooks is compensation based on non classification system, because it has the smallest amount of difference, therefore it most likely to be achieved. This is also 
strengthened by the fact that a shop at home industry level have a slight different capacity, therefore the compensation system with the classification analysis would be difficult to be applied for the aggregates or clusters calculation as done in this study. In order to enhance the competitiveness and productivity, the shop owner may use the results of compensation based on salary surveys that have been done throughout this study, where the shop owners who employ Indonesian cooks which are identified in under paid condition are expected to increase the salaries of cooks with a total of RM 4,036.99 for 7(seven) shops per month where the details is shown in Table 9.

Table 9 The Details of Total Funding for Adjustment Based on Ideal Compensation System of Non Classification for Indonesian Cook in KL, 2016

\begin{tabular}{ll}
\hline \multicolumn{1}{c}{ Shop } & $\begin{array}{c}\text { Total Operational Cost for } \\
\text { Employee Adjustment } \\
\text { (RM/Month) }\end{array}$ \\
\hline KB2 & 914.60 \\
KB3 & 706.69 \\
CK1 & 376.37 \\
CK2 & 719.13 \\
KB4 & 553.52 \\
KB5 & 662.32 \\
CK4 & 104.36 \\
\hline TOTAL & 4036.99 \\
Explanation: & \\
KB2= Kampung Baru 2 (Second Shop which is located in Kampung Baru \\
as the sample in this research that employ Indonesian Cooks); \\
KB3= Kampung Baru 3; \\
KB4=Kampung Baru 4; \\
CK1= Chow Kit 1; CK2= Chow Kit 2; \\
CK4= Chow Kit 4
\end{tabular}

Source: Data processed (2016)

Table 9 shows the shops of KB2, KB3, KB4, KB5, CK1, CK2, and CK4 have Indonesian cooks which the salaries are under paid, so it is advisable to increase the salaries of Indonesian cooks with the funding amount in Table 11.

Additionally, based on the calculation of non classification compensation system of job value on the sample of Indonesian cooks in KL by salary survey that have been conducted by researcher, the ideal average of bottom margin salary and the upper margin salary (all in/includes meal and allowances) and the ideal basic salary of Indonesian cooks at home industry level in KL could be seen in Table 10. 
AFEBI Management and Business Review (AMBR)

Vol.02 No.02, December 2017

Table 10 The Ideal Salary (all in) and the Basic salary for Indonesian Cooks in

KL 2016

\begin{tabular}{|c|c|c|c|c|c|c|}
\hline \multirow{3}{*}{ Position } & \multicolumn{4}{|c|}{ Ideal Salary (all in) } & \multirow{2}{*}{\multicolumn{2}{|c|}{ Ideal Basic Salary }} \\
\hline & \multicolumn{2}{|c|}{$\begin{array}{c}\text { Average of Bottom } \\
\text { Salary Margin } \\
\end{array}$} & \multicolumn{2}{|c|}{$\begin{array}{c}\text { Average of Upper Salary } \\
\text { Margin } \\
\end{array}$} & & \\
\hline & $\mathbf{R M}$ & $\mathbf{R p}$ & $\mathbf{R M}$ & $\mathbf{R p}$ & $\mathbf{R M}$ & $\mathbf{R p}$ \\
\hline Cooks & $2,051.06$ & $6,563,392.00$ & $3,044.87$ & $9,743,584.00$ & $1,743.06$ & $5,577,792.00$ \\
\hline $\begin{array}{l}\text { Senior Cooks } \\
\text { Assistant }\end{array}$ & $1,706.14$ & $5,459,648.00$ & $2,532.82$ & $8,105,024.00$ & $1,398.14$ & $4,474,048.00$ \\
\hline $\begin{array}{l}\text { Junior Cooks } \\
\text { Assistant }\end{array}$ & $1,488.15$ & $4,762,080.00$ & $2,209.21$ & $7,069,472.00$ & $1,180.15$ & $3,776,480.00$ \\
\hline
\end{tabular}

Source: Data processed (2016)

The determination of cooks' classification could be adjusted to the rules of core competencies in SKKNI for Social Services Sector and Individual Services Sector Enterprises Food. The average salary at bottom margin and upper margin and also the ideal basic salary then expected to become an input and consideration for Ministry of Manpower of the Republic of Indonesia and Indonesian Embassy in Kuala Lumpur to be informed for the ideal payroll system in accordance with the salary survey conducted for Indonesian Migrant Workers in Kuala Lumpur especially on cooks job cluster at home industry level which propose to enhance the external and internal equity and improve the productivity and welfare of Indonesian Cooks at home industry level in KL.

\section{Conclusions}

Based on the analysis, the conclusions of this study are:

1. The salary increase for each job position of Indonesian migrant workers at Cooks job cluster for home industry level in KL is not too extreme, but the Indonesian cooks' salary distribution are considerable enough for every job level in cooks job cluster and the existence of salary levels in several positions which are not hierarchical cause the compensation condition of Indonesian migrant workers at Cooks job cluster in KL has not been ideal entirely.

2. The compensable factors or the order of factors which became the basis determination of salary on Indonesian migrant workers at Cooks job cluster for home industry level in KL are knowledge and skill, organizational capabilities, self reliance, self presentation, responsibility of supervising, responses to critics, and the influence of work result.

3. The ideal compensation system for Indonesian Migrant Cooks in KL is non classification system based on Hay Plan Method, in which the required funding is more efficient with the amount of RM 4,036.99 or about Rp.12,918,368.00 for 7(seven) shops that employ Indonesian cooks which are identified in under paid condition.

\section{Recommendations}

1. The result of the analysis shows that the ideal compensation system based on non classification could be implemented by stakeholders as policies both in short and long term to increase the welfare and productivity of Indonesian migrant workers at Cooks job cluster for home industry level in KL. Indonesian Migrant Cooks whose salary are identified in under paid conditions 
should receive a salary increase in order to achieve the bottom or minimum margin salary. Wherein, the Indonesian cooks with overpaid salary conditions could be rectified by expanding the job, in order to create internal equity at work.

2. The results of compensation system analysis based on job value with non classification calculations could become an input and consideration for Ministry of Manpower of the Republic of Indonesia and Indonesian Embassy in Kuala Lumpur to be informed regarding the ideal payroll system in accordance with the salary survey conducted for Indonesian Migrant Workers in Kuala Lumpur especially on cooks job cluster at home industry level.

3. The following research are encourage to analyze the compensation system based on job value of Indonesian Migrant Worker in other informal job, such as driver, caregiver, babysitter, gardener, child care and housekeeper to analyze the salary that should be applied according to the job value of migrant workers abroad.

\section{References}

De Pora A. (2011). Remunerasi, Kompensasi, dan Benefit. Jakarta: Rana Pustaka. ISBN: 978-602-19294-3-8.

Dessler, G. (2009). Human Resources Management An Asian Perspective. Singapore: Pearson Education South Asia Pte Ltd. ISBN: 97800131746176.

Hatman, S. (2016). Compensation System Design Based on Job Value at CV. Indopress Cemerlang Bogor. [Thesis]. Bogor: Bogor Agricultural University.

Kadarisman, M. (2012). Manajemen Kompensasi. Jakarta: RajaGrafindo Persada. ISBN: 9789797694364.

Kartika L., Jayawinangun, R., Mangkuprawira, TB S. (2016). Manajemen Kompensasi. Bogor: IPB Press. ISBN: 978-979-493-935-2.

Kaur, Amarjit. (2008). International Migration and Governance in Malaysia: Policy and Performance. Papers of UNEAC Asia, 22, 4-18.

Mansor, Z.D, Adnan, N. 2014. Factors Contributing for Malaysian Employees' Willingness to Accept International Assignment. International Journal of Economics and Management, 8 (S), $67-80$.

Maarif MS., \& Tanjung H. (2003). Teknik-teknik Kuantitatif Untuk Manajemen. Jakarta: Grasindo. ISBN: 979732236.

Martin, Philip. (2003). Managing International Labor Migration In The $21^{\text {st }}$ Century. South East Europe Journal of Economics 1, ASECU SEEJE, 1, 9-18.

Mondy, R.W. (2008). Manajemen Sumber Daya Manusia. Jakarta: Erlangga. ISBN: 9789790337749.

Pandey, J. (2012). A Study On Job Evaluation - Point Factor Analysis in SME's. Asian Journal of Research in Business Economics and Management, Volume 2, Issue 5, ISSN: 2249-7307.

Rakasima, M F. (2011). Ensiklopedia TKI, Kebijakan dan Organisasi Penempatan dan Perlindungan Tenaga Kerja Indonesia. Jakarta: BNP2TKI. 
Rivai, V. (2005). Manajemen Sumber Daya Manusia Untuk Perusahaan. Jakarta: RajaGrafindo Persada. ISBN: 9789797697761.

Schuler R.S, \& Jackson S.E. (2000). Strategic Human Resource Management. Oxford: Blackwell Publishers. ISBN: 0-631-21600-6.

Siagian, S.P. (2008). Manajemen Sumber Daya Manusia. Jakarta: Bumi Aksara. ISBN: 9789795261001.

Sugiyono. (2013). Metode Penelitian Kombinasi. Bandung: Alfabeta. ISBN: 9786029328066.

Sugiyono. (2013). Metode Penelitian Kualitatif RnD. Bandung: Alfabeta. ISBN: 9798433640.

Sumarsono, HM. S. (2004). Metode Riset Sumber Daya Manusia. Yogyakarta: Graha Ilmu. ISBN: 979-3289-72-4.

Yusliana, I. (2014). Design of Financial Incentive System Based on Performance For Civil Servants in IPB. [Thesis]. Bogor: Institut Pertanian Bogor. 